\title{
Od kronologije prema teorijskim konceptima - iseljenička problematika u hrvatskoj historiografiji na uzorku radova objavljenih u Časopisu za suvremenu povijest
}

\author{
IVAN HRSTIĆ \\ Institut društvenih znanosti Ivo Pilar \\ Zagreb, Hrvatska \\ Ivan.Hrstic@pilar.hr \\ MARICA MARINOVIĆ GOLUBIĆ \\ Institut društvenih znanosti Ivo Pilar \\ Zagreb, Hrvatska \\ Marica.MarinovicGolubic@pilar.hr
}

\begin{abstract}
U članku se na temelju 39 radova posvećenih iseljeničkoj tematici, objavljenih u Časopisu za suvremenu povijest od 1969. do 2018., analizira istraženost povijesti hrvatskoga iseljeništva unutar hrvatske historiografije. Analiza je provedena na dvije razine. $S$ jedne strane problematizirana je opća (pod)zastupljenost navedene tematike u kontekstu cjelokupne hrvatske historiografije, a potom je postavljeno pitanje utjecaja dominantnoga narativa na istraživanje kroz tri ključne domene: izbor tema, upotreba karakteristične metodologije te sama interpretacija. Pritom su odvojeno promatrana dva razdoblja, za vrijeme Socijalističke Federativne Republike Jugoslavije te po ostvarenju samostalnosti Republike Hrvatske. Usporedno s tim dijelom analize osnovne karakteristike radova na temu hrvatskoga iseljeništva kontekstualizirane su s dosezima stranih historiografija te srodnih znanstvenih disciplina s aspekta primjene teorijskih i metodoloških okvira istraživanja.
\end{abstract}

Ključne riječi: hrvatsko iseljeništvo; historiografija; društvena povijest; interdisciplinarnost; Časopis za suvremenu povijest

Masovne migracije jedan su od ključnih modernizacijskih procesa, bilo iz perspektive iseljeničkih ili useljeničkih društava, a dijaspore su jedna od najvidljivijih, ali i najkontroverznijih manifestacija općega procesa globalizacije. ${ }^{1}$

1 U hrvatskoj historiografiji pojmovi iseljeništvo i dijaspora koriste se najčešće kao istoznačnice, pa će tako biti i u ovom radu. Ipak, mora se primijetiti da su pojedini autori uočili da se pojam „dijaspora” u većoj mjeri koristi u kontekstu hrvatskih iseljeničkih zajednica u europskim 
Prema istraživanjima Ujedinjenih naroda, na svijetu je 2015. bilo 244 milijuna međunarodnih migranata, a ako se njima pridruže pripadnici dijaspora druge, treće ili čak četvrte generacije, bez dvojbe možemo govoriti o apsolutnoj nužnosti boljega razumijevanja procesa njihove integracije u useljeničkim društvima te održavanja veza s društvima podrijetla. ${ }^{2}$ Povijesna važnost toga procesa ne može se precijeniti, a to je jasno vidljivo i u kontekstu aktualne migrantske krize koja se odvija u Europi od 2015. uslijed velikoga migracijskog vala s područja afričkih i azijskih država prema zemljama Europske unije. Istovremeno bolje povezivanje europskih zemalja s njihovim dijasporama na drugim kontinentima pruža veliku mogućnost razvoja svih aspekata društvenoga života na „starom” kontinentu. ${ }^{3} \mathrm{Da}$ bi se to postiglo, nužno je bolje razumijevanje povijesnoga razvoja njihovih iseljeničkih zajednica te cjelokupnoga fenomena migracija. Posebno to dolazi do izražaja u kontekstu naglašeno iseljeničkih nacija tijekom povijesti, kao što su Hrvati. Naime, prema procjeni Središnjega državnog ureda za Hrvate izvan Republike Hrvatske, danas diljem svijeta živi oko 3 milijuna hrvatskih iseljenika i njihovih potomaka. Ukupno stanovništvo Republike Hrvatske prema popisu iz 2011. iznosi 4290 612, a prema nekim procjenama, do 2019. taj broj pao je ispod 4 milijuna. ${ }^{4}$ Stoga se opravdano postavlja pitanje istraženosti procesa nastanka i razvoja hrvatskih iseljeničkih zajednica diljem svijeta unutar hrvatske historiografije. Djelomičan odgovor na to pitanje cilj je ovoga rada, a bit će ponuđen na temelju analize radova posvećenih obradi iseljeničkih tema objavljenih u Časopisu za suvremenu povijest od početka njegova izdavanja 1969. do kraja 2018. godine. ${ }^{5}$

Za Časopis za suvremenu povijest bez ikakve zadrške može se reći da slovi za jednu od najuglednijih te najkvalitetnijih hrvatskih stručnih periodičkih publikacija s fokusom na povijesne teme od druge polovine XIX. stoljeća do najrecentnijih događanja. U tom smislu radovi koje objavljuje mogu se smatrati pouzdanim pokazateljem trendova unutar cjelokupne hrvatske historiografije, što će se i pokazati na temi povijesti hrvatskoga iseljeništva šire kontekstualizirajući radove objavljene u Časopisu. Časopis ove godine (2019.) slavi i pedesetu obljetnicu izlaženja, što je svakako veliki uspjeh svih uredništava koja su mu bila na čelu, pa se ovaj rad može smatrati i prigodnim.

zemljama, a „iseljeništvo" više pri obradi iseljenika u prekooceanskim zemljama. Uz te pojmove vrlo je često korištenje i pojma širega značenja „migracija”. Usp. GRBIĆ JAKOPOVIĆ, Multipliciranje zavičaja i domovina, 16.

2 McAULIFFE, RUHS, World Migration Report 2018, 2.

3 De HAAS, Engaging diasporas; FAIST, „Migrants as transnational development agents”, 21-42; KING, CHRISTOU, „Cultural geographies of counter-diasporic migration”, 103-119; SINATTI, HORST, „Migrants as agents of development”, 134-152.

4 „Demografi složni: Hrvatska ima manje od 4 milijuna stanovnika, ali postoji jedan ozbiljan problem".

5 Časopis za suvremenu povijest može se smatrati nasljednikom časopisa Putevima revolucije, koji je izdavao Institut za historiju radničkog pokreta od 1963. do 1967. godine. Usp. KRIŠTO, „Hrvatska historiografija kroz trideset godišta Časopisa za suvremenu povijest”, 171. 
Uzorak definiran na ovaj način omogućuje donošenje zaključaka o osnovnim karakteristikama i tendencijama unutar područja; obrada cjelokupne historiografije bila bi teško izvediv zadatak, osobito s obzirom na sve veću produkciju historiografskih djela u posljednja dva desetljeća. Pri analizi radova posebna pozornost obratit će se na mogućnosti i perspektive za daljnja istraživanja, pritom osobito naglašavajući nužnost interdisciplinarnoga pristupa temi s obzirom na totalitet obilježja fenomena migracija. Istaknut će se i potreba intenzivnije primjene razrađenih teorijskih i metodoloških koncepata, $\mathrm{i}$ unutar historiografije i onih koji potječu iz drugih znanstvenih disciplina. Tim dijelom rada cilj nam je ujedno podsjetiti na vrlo važnu ulogu koju je Časopis za suvremenu povijest imao u kontekstu hrvatske historiografije, a to je njezino upoznavanje s teorijskim i metodološkim dosezima stranih historiografija. Posebno je do izražaja to dolazilo u vrijeme kada su informacije o novim znanstvenim postignućima putovale mnogo sporije, a dostupnost strane literature bila vrlo ograničena. Naime, na inicijativu Mirjane Gross, članice uredništva, u Časopisu su se od samoga početka poticali doktorandi povijesti na objavu radova o teorijskoj i metodološkoj problematici. Već 1974. ta je praksa i formalizirana pokretanjem rubrike „Problemi metodologije povijesti”, u sklopu koje su poslije objavljeni radovi i nekih od svjetskih „Zvijezda” historiografije, primjerice Françoisa Fureta, Michaela Mitterauera i Erica J. Hobsbawma. ${ }^{6}$ $\mathrm{Na}$ tom tragu problematizirat će se aktualni teorijski i metodološki pristupi u istraživanju povijesti migracija i iseljeništva, koji su u hrvatskoj historiografiji do sada bili korišteni u manjoj mjeri.

\section{Iseljeničke teme i hrvatska historiografija}

$\mathrm{U}$ analizi bilo kojega aspekta hrvatske historiografije u dužem razdoblju potrebno je prije svega naglasiti snažne promjene širega društvenoga konteksta koje su obilježile cijelo XX. stoljeće. Njih su pratile i promjene dominantnih narativa o nekim od ključnih povijesnih događaja i procesa. To vrijedi i u slučaju istraživanja povijesti hrvatskoga iseljeništva, koje je u svim razdobljima nastavilo održavati snažne veze s domovinom te imalo aktivnu ulogu u brojnim društvenim procesima. Veći dio XX. stoljeća među iseljenicima je prevladavao negativan odnos prema političkom, ali i društveno-gospodarskom sustavu u Hrvatskoj, pa su u skladu s tim i njihove aktivnosti bile usmjerene na njegovu kritiku te iniciranje promjena. Stoga je istraživanje ove teme bilo posebno osjetljivo. Naravno, utjecaj politike, odnosno ideologije na humanističke i društvene znanosti nije nikakva hrvatska specifičnost, no s obzirom na totalitarni i/ili autoritarni karakter država u kojima se Hrvatska većinu toga vremena nalazila, pri čemu se pri promjenama u pravilu događao oštar prekid $s$ prethodnom interpretacijom prošlosti, njihov utjecaj dodatno je dolazio do izražaja. U analizi znanstvenih radova on se može očitovati na tri razine - po

${ }^{6}$ JANKOVIĆ, Mijenjanje sebe same, 80. 
izboru teme, upotrijebljenoj metodologiji u istraživanju te samoj interpretaciji. Ta tri aspekta bit će aktualizirana i u analizi radova posvećenih iseljeničkim temama u Časopisu za suvremenu povijest. Pritom je potrebno naglasiti ograničene mogućnosti donošenja zaključaka u ovom pitanju jer dominacija određene teme odnosno upotreba konkretne metodologije, pa i sama interpretacija, ne mora podrazumijevati izravan ili neizravan (samocenzura) utjecaj vladajućih struktura i ideologije na znanost. Svi ti aspekti procjene mogu biti jednostavno i pokazatelji širega trenda unutar historiografije, i domaće i europske odnosno svjetske, te odraz duha vremena u kojem rad nastaje. U tom je kontekstu konkretno ovo istraživanje relativno nezahvalno jer je marksizam, kao dominantna ideologija unutar socijalističke Jugoslavije, tijekom druge polovine XX. stoljeća snažno utjecao i na razvoj „zapadnih” historiografija. To se potvrdilo i kontekstualizacijom analize radova posvećenih migracijama, odnosno iseljeničkoj i dijasporskoj problematici, objavljenih u Časopisu za suvremenu povijest.

U Časopisu su tijekom pedeset godina (136 svezaka, među kojima je osam dvobroja te dva trobroja) ukupno objavljena 1043 znanstvena rada. ${ }^{7}$ Među njima je 39 radova za koje je procijenjeno da su u većoj ili manjoj mjeri posvećeni iseljeničkim temama te su formirali uzorak za daljnju obradu. Dakle, manje od 4 \% ukupne bibliografije Časopisa radovi su koji se mogu povezati s temom povijesti hrvatskoga iseljeništva. S obzirom na intenzitet migracija tijekom povijesti, o čemu je već nešto rečeno, kao i snagu posljedica koje taj društveni proces ima na cjelokupni društveni razvoj u iseljeničkim i useljeničkim državama, definitivno se može zaključiti da se temi pridavalo vrlo malo pozornosti. To nije specifična karakteristika Časopisa za suvremenu povijest nego općenito stanje hrvatske historiografije u ovom pitanju, unutar koje se praktički tek nekolicina povjesničara profilirala kao stručnjaci u području u užem smislu. Među njima prije svega valja istaknuti Ljubomira Antića i Ivana Čizmića kao svojevrsne pionire istraživanja povijesti hrvatskoga iseljeništva, s naglaskom na prekooceanske useljeničke zemlje. U osvrtu na relativno malu zastupljenost iseljeničkih tema unutar cjelokupne historiografije ipak se mora naglasiti da je broj monografija posvećenih toj problematici znatno veći od broja radova objavljenih u znanstvenim časopisima, osobito u posljednja tri desetljeća. No, autori tih knjiga u velikoj su mjeri sami iseljenici - aktivni sudionici događaja ili pak publicisti. Stoga je u tom korpusu literature izostanak primjene razrađenije historiografske metodologije te kronološki pristup u odnosu na uže definirane historiografske radove dodatno naglašen. Tematski je, kao i u slučaju historiografskih znanstvenih radova, naglašen fokus na istaknute pojedince i organizacije, posebno iz političke sfere društvenoga razvoja, o čemu će još biti riječi.

Više je razloga za relativno malen broj radova posvećenih ovoj temi i uglavnom su vrlo objektivni. Spomenuta je njezina visoka politiziranost s obzirom na aktivnosti iseljeništva veći dio XX. stoljeća s ciljem rušenja političkoga poretka

7 JELASKA MARIJAN, „Pedeset godina Časopisa za suvremenu povijest”, 76. 
u Hrvatskoj, što je rezultiralo njezinom manjom atraktivnosti. Valja napomenuti da migracijske studije u osnovi možemo razdvojiti na istraživanje samoga čina migracije te istraživanje etničkih zajednica. ${ }^{8}$ Hrvatski povjesničari dominantno su se usmjerili na potonji aspekt fenomena. $U$ tom tipu istraživanja poseban je problem teška dostupnost izvora i arhivske građe kao temelja znanstvenoga istraživanja i strane literature koja bi omogućila kontekstualizaciju razvoja hrvatskih iseljeničkih zajednica. Taj problem posebno dolazi do izražaja ako bi se htjelo istraživati svakodnevni život iseljenika te cjelokupni društveni razvoj iseljeničkih zajednica pristupom „odozdo”. U tom slučaju nužan je odlazak u arhive useljeničkih zemalja te u same iseljeničke zajednice. Stoga su se hrvatski povjesničari u svojim radovima uglavnom fokusirali na istaknute pojedince i organizacije $u$ iseljeništvu, o kojima su mogli doći do više podataka bez odlaska u inozemstvo jer su njihov rad pratile institucije u Hrvatskoj, odnosno Jugoslaviji, a pojedini privatni i arhivi organizacija donacijama su vraćeni u Hrvatsku. Usto su relativno dostupne emigrantske novine i druge periodičke publikacije preko kojih se može pratiti njihovo djelovanje.

\section{Iseljenička problematika u Časopisu za suvremenu povijest do 1991. godine}

Sve navedeno odrazilo se i na zastupljenost radova posvećenih iseljeničkoj problematici u Časopisu za suvremenu povijest, kao i na njihovu tematsku profiliranost. S obzirom na potencijalni utjecaj ideologije, promatranih pedeset godišta Časopisa mogu se podijeliti na dva razdoblja: za vrijeme Socijalističke Federativne Republike Jugoslavije (SFRJ) i po proglašenju samostalnosti Republike Hrvatske. Do 1991. tiskana su 22 godišta Časopisa, u kojima je bilo 15 radova posvećenih iseljeničkoj problematici, a u idućih 28 godišta objavljena su 24 rada. Na temelju toga može se donijeti zaključak o blagom porastu popularnosti iseljeničkih tema, koji je nešto izraženiji kada se uzme u obzir da je od 15 radova objavljenih u prvom promatranom razdoblju čak pet objavljeno u prvom broju 1977., posvećenom jugoslavensko-austrijskim odnosima, odnosno položaju slovenske i hrvatske manjine u Austriji. ${ }^{9}$ Taj tematski broj bio je aktualan jer je 1976. Republika Austrija donijela zakon o pravnom položaju manjina, koji je u Jugoslaviji bio oštro kritiziran. Zato ti radovi u određenoj mjeri odstupaju od nekih osnovnih karakteristika ostatka analiziranoga korpusa. Jedini su koji su posvećeni hrvatskim manjinama u okolnim zemljama te se u većoj mjeri bave razdobljem nakon Drugoga svjetskog rata, a i naglašeno su angažirani.

8 KING, „Towards a new map of European migration”, 91.

9 ZORN, „Manjinsko pitanje”, 25-46; VUKAS, „Međunarodnopravna zaštita narodnih manjina u Austriji”, 47-68; VALENTIĆ, „Obilježja povijesnog razvitka Gradišćanskih Hrvata”, 95108; VALENTIĆ, „Školska problematika Gradišćanskih Hrvata”, 121-132; VALENTIĆ, „O denacionalizaciji Gradišćanskih Hrvata”, 171-178. 
Ostali radovi bave se uglavnom hrvatskim iseljenicima u prekooceanskim zemljama prije te za vrijeme Drugoga svjetskog rata. Aktivnostima iseljenika u europskim zemljama nešto više pozornosti posvetila je Mira Kolar Dimitrijević u radu o jugoslavenskim komunistima diljem Europe u međuratnom razdoblju, Fikreta Jelić-Butić u analizi djelovanja ustaša do Drugoga svjetskog rata te Petar Strčić u životopisu Ante Cilige. ${ }^{10} \mathrm{U}$ tom kontekstu može se na općoj razini primijetiti izostanak problematizacije procesa iseljavanja, odnosno razvoja iseljeničkih zajednica nakon Drugoga svjetskog rata, kada iseljenici razvijaju vrlo zapaženu aktivnost, no koja je u najvećoj mjeri bila usmjerena protiv Jugoslavije. U tom pogledu bavljenje temom bilo je vrlo osjetljivo pitanje. Naravno, pritom valja imati na umu i nepostojanje izraženije vremenske distance u odnosu na događaje koji su se mogli analizirati, pa se ova opaska u većoj mjeri odnosi na osamdesete godine XX. stoljeća, tj. završno razdoblje unutar prve promatrane historiografske etape. Ipak se istovremeno mora primijetiti zastupljenost poslijeratnih tema vezanih uz druge aspekte povijesnoga razvoja unutar historiografije, koje su bile više u skladu s dominantnim sustavom vrijednosti, čime taj argument o nedovoljnoj vremenskoj distanci gubi na snazi. ${ }^{11}$

S druge strane među analiziranim radovima o iseljeništvu na prvi pogled uočava se zastupljenost tema o aktivnostima Komunističke partije Jugoslavije $\mathrm{u}$ iseljeništvu, doprinosu iseljenika narodnooslobodilačkoj borbi ${ }^{12}$ te jugoslavenskim dobrovoljcima u Španjolskom građanskom ratu. ${ }^{13} \mathrm{Na}$ temelju naslova moguće je postaviti tezu o određenom utjecaju ideologije na izbor tema istraživanja, posebno s obzirom na prije uočen izostanak tema vezanih uz protujugoslavenski orijentirane iseljenike. No, kada se uzme u obzir broj radova posvećenih potencijalno „poželjnim” temama u ukupnom broju te da se svi oni temelje na istraživanju novina i periodičkih publikacija dostupnih u domaćim knjižnicama odnosno arhivskim fondovima koji se čuvaju u Zagrebu ili Beogradu, skloniji smo ipak zaključiti da je u većoj mjeri na izbor tema utjecala spomenuta ograničena dostupnost izvora. Sve obrađene teme neupitno su važne, a radovi utemeljeni u izvorima i relevantnoj literaturi, u skladu sa standardima struke u vremenu kada su nastali, ne ulazeći u kvalitetu pojedinih radova u užem smislu. Naravno, nikako se ne želi niti smije podcijeniti općeniti utjecaj konteksta vremena i prostora na povjesničare, koji uostalom sve koji se bave ovom znanosti oblikuje bez obzira na to u kojem trenutku i na kojem

10 KOLAR-DIMITRIJEVIĆ, „Odnos KPJ prema jugoslavenskoj radničkoj emigraciji”, 65-83; JELIĆ-BUTIĆ, „Prilog proučavanju djelatnosti ustaša do 1941., 55-91; STRČIĆ, „Prilog za biografiju Ante Cilige", 15-49.

11 Od 1969. do 1991. u Časopisu za suvremenu povijest objavljeno je 27 znanstvenih radova posvećenih temama povijesti Jugoslavije nakon 1945. godine. Zbog prostora predviđenog za ovaj članak ti se radovi ne navode posebno, no jednostavno ih je identificirati u bibliografiji Časopisa.

12 ANTIĆ, „Prilog istraživanju odnosa naših iseljenika u Južnoj Americi prema NOB-u”, 43-80.

13 KOPRIVICA-OŠTRIĆ, „Jugoslavenski dobrovoljci”, 1-26. 
mjestu živjeli i radili. Taj aspekt istraživanja posebno dolazi do izražaja u domeni autocenzure. Bavljenje temama koje su bile u skladu s dominantnim sustavom društvenih vrijednosti zasigurno je bilo poželjno, ali za donošenje utemeljenih zaključaka o izravnom utjecaju politike na izbor istraživačkih tema iz povijesti iseljeništva, kao i prisutnosti odnosno intenzitetu samocenzure u njihovu izboru, bilo bi potrebno provesti šire istraživanje politike financiranja istraživačkih projekata, pa i zapošljavanja znanstvenika, odnosno eventualnih sankcija za povjesničare koji su se bavili pitanjima koja nisu bila u skladu s dominantnim sustavom normi i vrijednosti. Samo na temelju analize manjega broja radova slične zaključke nije moguće odgovorno donositi.

Veća je pak mogućnost zaključivanja u pitanju metodologije korištene u istraživanjima. U tom cilju moguće je analizirane radove kontekstualizirati unutar cjelokupne hrvatske historiografije te usporediti nalaze s nekim širim europskim i svjetskim trendovima. Tu prije svega valja istaknuti tendencije prisutne u domaćoj znanosti 1970-ih i 1980-ih u primjeni modernih teorijskih i metodoloških pristupa istraživanju, osobito na tragu škole Annales. Glavnina nastojanja toga tipa vodila je u smjeru snažnijega razvoja društvene povijesti, koja je zagovarala pomicanje fokusa na istraživanje socijalnih procesa, odnosno odmicanje od tradicionalne usko shvaćene političke događajnice. Taj trend nije postao dominantan iako se unutar hrvatske historiografije mora primijetiti u to vrijeme karakterističan snažniji razvoj ekonomske povijesti, povijesne demografije i primjene kvantitativnih metoda, odnosno začeci istraživanja povijesti žena, povijesti svakodnevice i povijesne antropologije. ${ }^{14}$

Po tim pojavama hrvatska historiografija samo je slijedila smjer kojim se mnogo intenzivnije razvijala povijesna znanost na europskoj i svjetskoj razini. „Zapadne" historiografije u to su vrijeme u velikoj mjeri posvećivale pozornost društvenoj povijesti te istraživanju društvenih procesa u dugom trajanju, nastojeći doći do „velikih” zaključaka i objašnjenja društvenih procesa jedinstvenim teorijama. U području istraživanja migracija sve su snažnije bile kritike dominantne teorije iz prethodnoga razdoblja, teorije potisno-privlačnih faktora. Njezin fokus bio je na interpretaciji migracijskih procesa kao posljedice racionalnih individualnih odluka pojedinaca. Kao reakcija uslijedio je razvoj teorija koje su naglašavale važnost utjecaja obiteljskoga iskustva na odluku o migraciji, kao i iskustava šire zajednice. Već tijekom 1970-ih usporedno se razvijao povijesno-strukturalistički pristup temeljen na marksističkoj političkoj ekonomiji i teoriji svjetskoga sustava. Unutar toga sklopa misli migracijska kretanja nastojala su se objasniti utjecajem ekonomske moći na štetu siromašnijih društava i zemalja, podižući fokus s individualne mikrorazine na institucijsku makrorazinu. ${ }^{15}$ Pritom su pojedinci - migranti prešli put od aktivnih kreatora svojih odluka do praktički pasivnih objekata pod utjecajem širega društvenoga konteksta. Važno je u tom kontekstu skrenuti pozornost na razvoj tzv. nove useljeničke povijesti (engl. new immigration history) i etničkih studija (engl.

\footnotetext{
14 JANKOVIĆ, Mijenjanje sebe same, 19, 129.

15 GRBIĆ JAKOPOVIĆ, Multipliciranje zavičaja i domovina, 26-27.
} 
ethnic studies) kao interdisciplinarnih polja u velikim useljeničkim društvima koja upravo 1970-ih i 1980-ih ostvaruju snažan iskorak. Osnovna karakteristika tih grana historiografije bio je pristup istraživanju „odozdo”, s fokusom na svakodnevna iskustva „običnih” ljudi, njihov privatni život i društvene odnose, te posvećivanje pozornosti u ranijoj literaturi marginaliziranim grupama kao što su primjerice žene i djeca. ${ }^{16}$

Time se na međunarodnoj razini od 1970-ih može pratiti usporedni razvoj makroanaliza, mikroanaliza i mezoanaliza. Makropristupi i mikropristupi bili su karakteristični za starije teorije, a novije u prvi plan stavljaju mezorazinu. Pritom se pod pojmom makrostruktura podrazumijevaju međudržavni odnosi, institucije, zakoni itd. Mikrostrukture s druge strane obuhvaćaju individualne socijalne mreže pojedinaca, a mezostrukture niz posredničkih mehanizama koji omogućavaju povezivanje makrorazine i mikrorazine te njihovu interakciju, kao što su primjerice iseljeničke agencije i agenti, banke, prijevoznici. Mikropristup i perspektiva bazira se na racionalnosti odluke migranta, no pritom se donekle zanemaruje utjecaj širega društvenoga konteksta. Stoga autori koji se u svojem radu fokusiraju na pojedinca, što je relativno čest slučaj u hrvatskoj historiografiji, $\mathrm{u}$ interpretacijama moraju imati na umu mogućnost utjecaja metodološkoga individualizma na donošenje zaključaka, odnosno objašnjavanje povijesnih događaja isključivo osobinama toga pojedinca. S druge strane u makroperspektivi pojedinci su u velikoj mjeri svedeni na pasivnu ulogu u odnosima među državama i institucijama, a njihovo djelovanje uvjetovano je silnicama globalnoga svjetskoga ekonomskog poretka. ${ }^{17} \mathrm{U}$ tom smislu zanemaruje se cijeli niz osobnih motiva koji utječu na pojedinca pri formaciji odluke. ${ }^{18}$ Kao svojevrsni medijator između ta dva suprotstavljena pola razvio se mezopristup, čiji se korijeni mogu pronaći u teoriji migracijskih sustava nastaloj već 1970-ih. U njezinoj je osnovi teza o sustavu povezanih država koje izmjenjuju migrante, a uzroke kretanja nalazi u prije uspostavljenim vezama između tih država, kao što su primjerice politički odnosi, participacija u zajedničkoj masovnoj kulturi te obiteljske i socijalne mreže. Posebna pozornost u sklopu te teorije pridaje se pojedinačnim iskustvima iseljenika u prilagodbi na život u novom okruženju, pri čemu se sklopove individualnih iskustava definira kao socijalni kapital. ${ }^{19} \mathrm{U}$ idućim desetljećima na sličnom tragu objašnjenja koja uzimaju u obzir i osobne kalkulacije pojedinca i institucijske te globalne sile razvio se niz teorija, među kojima je posebnu popularnost stekla teorija društvenih mreža, s korijenima u sociologiji i antropologiji. Teorija naglašava važnost neformalnih i formalnih veza koje migrantima pomažu nositi se s migracijom, pri čemu su obitelj i zajednica ključna čvorišta migrantskih mreža. ${ }^{20}$

\footnotetext{
16 RUŽIĆ, „Immigration history”, 761-779.

17 ARANGO, „Explaining Migration”, 285-287; MARINOVIĆ GOLUBIĆ, „Useljavanje u tradicionalno iseljenička područja”, 17-18.

18 MARINOVIĆ GOLUBIĆ, „Useljavanje u tradicionalno iseljenička područja”, 10-11.

19 GRBIĆ JAKOPOVIĆ, Multipliciranje zavičaja i domovina, 27-28.

20 CASTLES, MILLER, The Age of Migration, 25.
} 
U hrvatskoj historiografiji posvećenoj temi iseljeništva identificiranje tih trendova otežano je s obzirom na relativno malen ukupan broj radova. Može se primijetiti određena dominacija mikropristupa istraživanjima, no pitanje je koliko je to bila odluka autora jer u radovima nije moguće pronaći izravne reference na strane autore ili pak teorije. S druge strane odabir tema istraživanja i njihova obrada bili su uvjetovani ili barem dobrim dijelom ograničeni nedostupnošću većega broja izvora, osobito onih raznovrsnijega karaktera. Slična situacija bila je i u pitanju dostupnosti strane literature koja bi omogućila širu kontekstualizaciju događaja i procesa. Time je u određenoj mjeri ograničena i mogućnost snažnije primjene makropristupa i/ili mezopristupa istraživanju. Kako je iseljeništvo kao tema općenito privlačilo pozornost tek uskoga kruga povjesničara, izostao je i snažniji poticaj njezinoj transformaciji u skladu s općim trendom razvoja teorijskih i metodoloških postavki historiografskih istraživanja. U skladu s tim, od primarnoga interesa zadržale su se „tradicionalne" teme, prije svega politička kretanja među iseljenicima, s naglaskom na istaknute pojedince (isključivo muškarce) i organizacije. ${ }^{21}$ To potvrđuje i uzorak radova objavljenih u Časopisu za suvremenu povijest, među kojima se može tek primijetiti pojava upotrebe kvantitativnih metoda ${ }^{22}$ u ovoj grani historiografije. S obzirom na ograničenu dostupnost relevantne literature o situaciji u zemljama useljenja i tamošnjim društvenim odnosima, interpretacija događaja $\mathrm{u}$ iseljeništvu $\mathrm{u}$ pravilu je slijedila događaje i društvene procese $\mathrm{u}$ Hrvatskoj. Pritom je izostao komparativni pristup istraživanju u odnosu na druge useljeničke nacionalne skupine, pa prikaz razvoja iseljeničkih zajednica ostaje jednodimenzionalan. Uz ovaj komentar valja naglasiti da se nikako ne želi dovesti u pitanje kvaliteta objavljenih radova, koja ne ovisi izravno o upotrijebljenoj metodologiji, iako bi njihovi nalazi uz korištenje šire teorijske interpretacije i kontekstualizacije omogućili i donošenje širih zaključaka te veći doprinos cjelokupnom poznavanju fenomena migracija.

Analiza interpretacija i metodoloških pristupa istraživanjima nije ustanovila znatniju prisutnost ideološke podloge. S obzirom na širi društveni kontekst socijalizma kao temeljne karakteristike vremena nastanka radova, pokušala se odrediti prije svega prisutnost marksističke misli. No, osnovna karakteristika proučenih radova tradicionalni je pristup istraživanju s relativno uskim fokusom na korištene izvore, koji se u velikoj mjeri citiraju ili neizravno prenose, a sama interpretacija u većoj mjeri često izostaje. Upotreba ideoloških koncepata i teza bila je prvenstveno „formalne”, u neku ruku i dekorativne prirode, bez izraženijega utjecaja na konačne zaključke. Pritom se svakako mora primijetiti nešto češća upotreba terminologije te stil pisanja u skladu s dominantnom marksističkom paradigmom, pa se komunisti, primjerice, u više radova

${ }^{21}$ Uz ostale radove objavljene do 1991. navedene u bilješkama i bibliografiji usp. i: ANTIĆ, „Pokušaj stvaranja 'Hrvatskog saveza”, 43-62; ČIZMIĆ, „Reagiranja jugoslavenskih iseljenika”, 99-107.

${ }^{22}$ Usp. KOPRIVICA-OŠTRIĆ, „Jugoslavenski dobrovoljci”, 1-26. 
etiketiraju kao „progresivni” i „napredni”. ${ }^{23}$ U tom duhu i Nada Hranilović, kada govori o Niki Grškoviću, navodi da se „za vrijeme Prvoga svjetskog rata borio $\mathrm{u}$ iseljeništvu za oslobođenje domovine od tuđinskog ropstva i stvaranje zajedničke države svih jugoslavenskih naroda”, a za list Zajedničar naglašava njegovu „izuzetno važnu ulogu u širenju istine o Narodnooslobodilačkoj vojsci, drugu Titu i narodnooslobodilačkoj borbi u cjelini”, kao i „posebne zasluge za upoznavanje našeg iseljeništva širom svijeta i cjelokupne američke i svjetske javnosti s narodnooslobodilačkom borbom i socijalističkom revolucijom". ${ }^{24}$ Ipak, slične formulacije prije su iznimka nego pravilo. To u određenoj mjeri potvrđuje i izostanak snažnije argumentacije teza, odnosno interpretacije povijesnih događaja i procesa u duhu historijskoga materijalizma.

Elementi takva pristupa mogu se tek vrlo rijetko pronaći u analiziranim radovima. Primjerice, Mira Kolar Dimitrijević zaključuje vezano uz Veliku gospodarsku krizu iz 1929. da je „pokazala svu neprilagođenost kapitalističkog sistema velikim privrednim stresovima. Radi obrane imperijalizma i kapitalizma vlasti pojedinih država sve koordiniranije istupaju protiv demokratskih i naprednih snaga". ${ }^{25} \mathrm{~S}$ druge strane Ljubomir Antić političke sukobe i razmirice među iseljenicima u Južnoj Americi za vrijeme Prvoga i Drugoga svjetskog rata objašnjava razlikama među socijalnim grupama, konkretno između uspješnih gospodarstvenika („buržoazije”) i radnika. Pritom je napomenuo da se u dotadašnjoj hrvatskoj historiografiji „povijesti hrvatskog iseljeništva uglavnom pristupalo kao socijalno kompaktnoj masi iz koje su stršili samo malobrojni pojedinci, i to oni koji su se afirmirali u kulturnom i znanstvenom životu zemlje imigracije i s kojima se 'masa' ponosila, gledajući u njima potvrdu vrijednosti iseljene nacionalne grupe kojoj su pripadali”. ${ }^{26}$ No, isto tako u interpretaciji naglašava da se unatoč toj podjeli po društvenom položaju i statusu ne može govoriti o klasnoj borbi jer nešto slično u okviru tako malobrojne grupe nije moguće. Dalje dodaje: „Ukoliko su naši iseljenici sudjelovali u klasnim borbama u Čileu u vremenu o kojem je ovdje riječ, borili su se integrirani u tadašnje klase čileanskog društva. To, međutim, tek treba istražiti." ${ }^{27}$ Time je ujedno naznačio smjer u kojem bi se proučavanje povijesti iseljeničkih zajednica moglo razvijati, što bi bilo u skladu sa širim trendovima unutar struke s naglaskom na socijalnoj stratifikaciji i istraživanju širega konteksta useljeničkih društava. Neizravno je time Antić potvrdio poznavanje onodobne europske i svjetske historiografske literature, ali je naznačio i ograničene mogućnosti istraživanja

${ }^{23}$ HRANILOVIĆ, „List 'Zajedničar”, 26, 31-33; ANTIĆ, „Prilog istraživanju odnosa naših iseljenika u Južnoj Americi prema NOB-u”, 68; ČIZMIĆ, „Reagiranja jugoslavenskih iseljenika”, 99, 105; KOLAR-DIMITRIJEVIĆ, „Odnos KPJ prema jugoslavenskoj radničkoj emigraciji”, 71, $76,78,81,83$.

${ }^{24}$ HRANILOVIĆ, „Novinarska djelatnost don Nike Grškovića”, 49; HRANILOVIĆ, „List 'Zajedničar"', 19-20.

${ }_{25}$ KOLAR-DIMITRIJEVIĆ, „Odnos KPJ prema jugoslavenskoj radničkoj emigraciji”, 71.

26 ANTIĆ, „Sukobi u jugoslavenskom iseljeničkom pokretu u Antofagasti”, 41.

27 Isto, 42. 
za hrvatske povjesničare uslijed slabe dostupnosti arhivskih izvora i literature kao ključnoga čimbenika koji bi slične analize omogućio.

Dakle, u kontekstu svega zaključenog u analizi utjecaja politike, odnosno ideologije na domaću historiografiju može se sumirati da u samim analiziranim tekstovima objavljenim u Časopisu za suvremenu povijest o temi iseljeništva do 1991. ne postoji snažnija ideološka angažiranost na temelju koje bi se mogao ustvrditi izravan utjecaj vladajućih struktura na znanost. S druge strane postoje naznake o njihovu izravnom i/ili neizravnom utjecaju na izbor tema kojima su se povjesničari češće odlučivali baviti, no za potvrdu ove pretpostavke potrebno je šire istraživanje.

\section{Iseljenička problematika nakon 1991. godine}

Raspadom socijalističke Jugoslavije i ostvarenjem samostalnosti Republike Hrvatske te uvođenjem demokracije širi društveni kontekst doživio je iznimno snažnu promjenu, što se posljedično odrazilo i na historiografiju. Prije svega valja istaknuti povećani interes za teme koje u prethodnom razdoblju nisu bile istraživane, među kojima je i povijest iseljeništva, te reinterpretaciju onih tema kojima se prije posvećivalo više pozornosti, ali na koje je utjecaj ideologije bio više izražen s obzirom na simboličku težinu koju su nosile u cjelokupnom sustavu vrijednosti. Stoga je suvremenom hrvatskom historiografijom nastavila dominirati politička povijest, a povjesničari posvećeni istraživanju prijašnjih razdoblja, osobito medievisti, u sve većoj mjeri pratili su moderne europske i svjetske trendove primjenjujući nove teorijske i metodološke okvire u svojim istraživanjima. ${ }^{28}$ Te trendove karakteriziralo je sve intenzivnije proučavanje društvene povijesti te razvoj brojnih poddisciplina, među kojima su vrlo popularne postale kulturalna povijest, transnacionalna povijest, povijest emocija, povijest okoliša, javna povijest itd.

U modernoj hrvatskoj historiografiji, a posebno onoj posvećenoj temama iseljeništva, ti su se trendovi razvijali mnogo sporije. Osnovni okvir i dalje je karakterizirao relativno malen broj povjesničara koji se bave tom temom. Razvoj tehnike i tehnologije, odnosno sve veća dostupnost literature preko interneta, pa i samih arhivskih izvora, kao i sve veće mogućnosti istraživačkoga boravka u inozemstvu sporo su se odražavali na ovo historiografsko polje. Politička i intelektualna povijest usmjerena na istaknute pojedince i organizacije nastavila je privlačiti najveći interes istraživača s obzirom na to da su pojedini arhivi vezani uz temu dostupni u Hrvatskoj, odnosno njihov rad može se pratiti preko emigrantskoga tiska. Time je poljem nastavio dominirati mikropristup, no ipak

\footnotetext{
${ }^{28}$ U određenoj mjeri zasigurno je to bilo uvjetovano i relativnim nedostatkom izvora za ranija razdoblja, pa su za njihovu kritičku evaluaciju i kvalitetnije iskorištavanje povjesničari prije bili usmjereni na stranu literaturu i korištenje modernih pristupa istraživanju. S druge strane povjesničari koji se bave XX. stoljećem u pravilu imaju, može se reći, i previše izvora na raspolaganju, pa se u većoj mjeri oslanjaju isključivo na njih te dijelom izostavljaju postavljanje širega teorijskog okvira i kontekstualizaciju događaja nekim od društvenih procesa.
} 
vrijedi istaknuti nekoliko radova koji upotrebom kvantitativne metodologije, pa i povijesne demografije ${ }^{29}$, te problematiziranjem širega konteksta razvoja iseljeničkih zajednica u useljeničkim društvima ${ }^{30}$ naznačuju historiografske iskorake primjenom novijih teorijskih i metodoloških pristupa, o kojima se tijekom toga vremena šira stručna javnost upoznaje upravo na stranicama $\check{C} a$ sopisa za suvremenu povijest. ${ }^{31} \mathrm{U}$ tom svjetlu mogu se promatrati i pokušaji kontekstualizacije djelovanja (po)najvažnijih institucija Kraljevine Jugoslavije i socijalističke Jugoslavije posvećenih odnosu s iseljenicima u cilju analize odnosa države prema iseljeništvu. ${ }^{32}$ Sve te „iznimke” vrijedi posebno istaknuti jer pri analizi razvoja historiografije nikada nije moguće govoriti o apsolutnoj dominaciji jednoga tipa istraživanja, a kada se iznimke toga tipa pojave u tako malom ukupnom broju radova kao u ovom slučaju, onda one mogu biti vrlo indikativne te same predstavljati novi trend ili barem njegov začetak.

U kontekstu istraživanja povijesti migracija na međunarodnoj razini tijekom 1990-ih snažan razvoj bilježi se u okviru studija dijaspore. Naime, tradicionalno se pod pojmom dijaspore podrazumijevala grupa ljudi snažnoga zajedničkog identiteta, povezana etno-lingvističkim ili vjerskim vezama, koja je napustila domovinu uglavnom pod nekim oblikom prisile. Klasični pristup dijaspori temeljio se na primjeru Židova te u manjoj mjeri Palestinaca i Armenaca, koji razvijaju specifičnu vrstu višestrukih identiteta jer se nikada ne asimiliraju u potpunosti, nego ostaju u određenom smislu autsajderi unutar useljeničkih društava. U tom kontekstu dolazi do snažnoga naglašavanja vlastitoga identiteta i „vječne žudnje” za povratkom u domovinu. Tijekom 1990ih pojam dijaspora počeo se koristiti unutar znanosti za sve zajednice s iskustvom migracije. ${ }^{33}$ Popularnost koju je od tada pojam stekao dovela je u stranoj humanistici i društvenim znanostima do kasnijega problematiziranja njegove korisnosti i funkcionalnosti uopće s obzirom na brojne interpretacije koje je primio. $^{34}$

Unutar studija dijaspore posebno je utjecajan postao tipološki pristup istraživanju iseljeničkih zajednica. Njegova je vrijednost što omogućava kontekstualizaciju i komparaciju te pruža okvir za razlikovanje političkih, ekonomskih i društvenih okolnosti u kojima dijaspore nastaju i djeluju. No, on

${ }^{29}$ AGIČIĆ, „Hrvatski studenti na češkom sveučilištu u Pragu”, 291-315; AGIČIĆ, „Hrvatski doktori u Pragu”, 137-154.

${ }^{30}$ Usp. KRIŠTO, „Čuvari svoje braće”, 407-430. U tom kontekstu može se analizirati i rad o odjecima događanja u Hrvatskoj tijekom Domovinskoga rata u Australiji, što se posljedično snažno odrazilo i na položaj hrvatske iseljeničke zajednice na tom kontinentu. Usp. BING, „Croatia down under", 769-802.

31 RUŽIĆ, „'Immigration history”, 761-779.

32 BUĆIN, „Iseljenički muzej u Zagrebu”, 363-389; KRALJEVIĆ, „Matica iseljenika Hrvatske 1964.-1968.", 71-92.

33 SAFRAN, „Diasporas in Modern Societies”, 83-99; AKENSON, „The Historiography of English-Speaking Canada and the Concept of Diaspora”, 377-410; GRBIĆ JAKOPOVIĆ, Multipliciranje zavičaja i domovina, 18.

34 BRUBAKER, „The 'diaspora' diaspora”, 1. 
istovremeno pojednostavnjuje kompleksnost dijaspore ignorirajući generacijske, spolne/rodne i druge razlike unutar zajednice te nastoji relativno statično objasniti izrazito dinamičan fenomen. Istraživanja utemeljena na tipološkom pristupu dijaspori nastoje identificirati osnovne karakteristike koje neku zajednicu čine dijasporom. Najutjecajnija tipologija jest ona Robina Cohena, koji je identificirao devet glavnih karakteristika dijaspore, ali je pritom naglasio da ih nijedna dijaspora ne sadržava sve, a za identitet pojedine ključnim je smatrao uzrok iseljavanja. Na temelju toga razlikuje žrtvoslovne, radne, trgovačke, imperijalne i kulturne dijaspore, ali naglašava da podjele nisu rigidne nego korisne karakterizacije ideal-tipova. ${ }^{35}$ To je u kontekstu hrvatske historiografije o iseljeništvu važno jer se $\mathrm{u}$ analiziranim radovima objavljenim u Časopisu za suvremenu povijest, a i šire, može uočiti karakterističan pristup istraživanju iseljeničkih zajednica s pretpostavkom o njihovoj homogenosti. Pritom se vrijedi opet referirati na opasku Ljubomira Antića u radu iz 1984. o karakterističnom pristupu povijesti hrvatskoga iseljeništva, koji karakterizira njegovo proučavanje u smislu „socijalno kompaktne mase”. Taj tip pozitivističkoga pristupa društvenom razvoju iseljeničkih zajednica ostao je jedna od osnovnih karakteristika istraživanja u hrvatskoj historiografiji. Njegovom se primjenom zanemaruje utjecaj različitih čimbenika na identitet svih iseljenika. Povod Antićevu komentaru bila je heterogenost iseljeničke populacije po socijalnom položaju i posljedično političkom opredjeljenju. U kontekstu istraživanja povijesti iseljeništva nakon 1945., koje je u radovima objavljenim nakon 1991. postalo dominantna tema, do snažnijega izražaja dolaze pak drugi čimbenici, a prije svih pripadnost različitim valovima iseljavanja ili generacijama, koja se potom odrazila i na njihove političke, odnosno ideološke stavove.

Dakle, nakon 1991. fokus istraživanja pomaknut je prema protujugoslavenski orijentiranim pojedincima i organizacijama aktivnima od 1945. do 1991., koje su za vrijeme Jugoslavije državne strukture etiketirale kao „neprijateljsku emigraciju” jer su zastupali ideju hrvatske neovisnosti i samostalnosti. ${ }^{36} \mathrm{U}$ tom

35 Devet Cohenovih ključnih obilježja dijaspore su: odlazak iz domovine (često traumatičan); alternativno - iseljavanje iz domovine u potrazi za poslom, trgovinom ili radi kolonijalnoga širenja; kolektivno sjećanje i mit o domovini; idealizacija „doma predaka”; povratno kretanje; snažna grupna etnička svijest; problematični odnosi s društvom useljenja; osjećaj solidarnosti sa sunarodnjacima u drugim društvima; mogućnost razvoja zasebnoga kreativnog i obogaćujućeg života u tolerantnim državama. Usp. COHEN, Global Diasporas, X-XI, 26.

36 Usp. BEDNJANEC VUKOVIĆ, „Prilozi o NDH u časopisu 'Hrvatska revija”, 73-96; BEUS, „Suradnja Dominika Mandića i Jere Jareba”, 503-534; JANDRIĆ, „Stajališta Hrvatske političke emigracije”, 431-461; JAREB, „Prilog povijesti hrvatskog iseljeništva u SAD-u”, 37-70; ŠARIĆ, „Bleiburške žrtve”, 505-521; TOMAS, „Pogled na život i djelo don Ivana Tomasa”, 39-59; BENCETIĆ, „Mons. Augustin Juretić”, 461-484. Uz te radove može se u tematskom smislu sagledati i rad Hrvoja Matkovića o djelovanju Jurja Krnjevića u sklopu jugoslavenske iseljeničke vlade u Londonu za vrijeme Drugoga svjetskog rata. Jedna od osnovnih teza naglašenih u radu jest ona o Krnjevićevoj obrani hrvatskih nacionalnih interesa. Slično se može sagledavati i rad Srđana Miloševića o aktivnostima Vladka Mačeka u iseljeništvu. Iako govori prvenstveno o vezama koje je Maček održavao s knezom Pavlom, uglavnom je posvećen Mačekovu stavu protiv socijalističke Jugoslavije. Usp. MATKOVIĆ, „Prilog proučavanju političke djelatnosti Jurja Krnjevića”, 93-106; MILOŠEVIĆ, „Emigrantska pisma Vladka Mačeka”, 299-322. 
kontekstu valja gledati i nešto veći interes za teme vezane uz aktivnosti ustaša $\mathrm{u}$ inozemstvu prije Drugoga svjetskog rata. ${ }^{37}$ To je istovremeno bila posljedica i povećanih mogućnosti bavljenja temom s obzirom na postojanje određene vremenske distance te veću dostupnost arhivskih izvora, ali i rezultat većega općega društvenog interesa za tu temu s obzirom na promjene širega političkog i društvenoga konteksta, odnosno prethodni izostanak njezina problematiziranja. S druge strane projugoslavenski element iseljeništva nakon Drugoga svjetskog rata praktički se počinje ignorirati, a teme iz povijesti radničkoga pokreta gotovo potpuno gube atraktivnost i prestaju biti problematizirane. ${ }^{38}$ Da stvar bude zanimljivija, tu jugoslavensku dijasporu većinom su, osobito u prekooceanskim zemljama, činili pripadnici starije generacije hrvatskih iseljenika koji su napustili Hrvatsku prije Prvoga svjetskog rata ili tijekom međuraća. U radovima posvećenim povijesti iseljeništva do Drugoga svjetskog rata njima se pristupa kao hrvatskom iseljeništvu iako je već tijekom Prvoga svjetskog rata među iseljenicima počela dominirati jugoslavenska ideja. U tom je smislu smanjenje interesa za istraživanje povijesnoga razvoja tih jugoslavenskih iseljeničkih zajednica nakon Drugoga svjetskog rata u određenoj mjeri i paradoksalno. $^{39}$

Osnovni razlog izbjegavanja istraživanja njihova razvoja nakon Drugoga svjetskog rata jest taj da su u međuvremenu iseljenici uglavnom pristali uz komunističke ideje te počeli podržavati ideju socijalističke Jugoslavije. S obzirom na širi društveni kontekst te položaj useljenika uglavnom u vodećim savezničkim silama, takav slijed događaja nije iznenađujući. No, dolaskom velikoga vala antikomunistički i protujugoslavenski orijentiranih Hrvata nakon Drugoga svjetskog rata u te iste zemlje formiraju se dvije zajednice, relativno snažno odvojene, pa i suprotstavljene sve do raspada SFRJ. Sukob između te dvije grupe obilježio je njihov razvoj u drugoj polovini XX. stoljeća i u velikoj mjeri oblikovao njihove identitete te postavio granice. No, znači li to da jugoslavenske iseljeničke zajednice od 1945. do 1991. u kojima su etnički Hrvati činili većinu više nisu dio povijesti hrvatskoga iseljeništva te ih nije potrebno istraživati? Kako onda interpretirati proces relativnoga ujedinjenja tih dviju zajednica nakon osamostaljenja Republike Hrvatske, kada u pravilu zajedno opet počinju činiti jedinstvenu hrvatsku iseljeničku zajednicu? ${ }^{40}$ Uostalom,

${ }^{37}$ JAREB, „Publikacije domobransko-ustaškog pokreta - I. dio”, 241-255; JAREB, „Publikacije domobransko-ustaškog pokreta - II. dio”, 413-426; JONJIĆ, MATKOVIĆ, „Novi prilozi za životopis Mile Budaka", 425-453.

${ }_{38}$ Svojevrsna je iznimka rad Michaela S. Foxa o Anti Ciligi, no on je ujedno uz Amy Schmidt i jedini strani autor obuhvaćen ovim istraživanjem, što u određenoj mjeri potvrđuje uočeno pravilo o izbjegavanju teme unutar hrvatske historiografije. Usp. FOX, „Ante Ciliga, Trocki i državni kapitalizam”, 427-449; SCHMIDT, „Vladko Maček i Hrvatska seljačka stranka”, 407-422.

39 Usp. HRSTIĆ, „Dnevnik Ivana Čovića”, 157-177; HAMERŠAK, „Josip Jedlowski”, 101-128; MARTINIĆ BEROŠ, „Nacionalno-političke kontroverze”, 735-759.

${ }^{40}$ Ujedinjenje nekad razdvojenih zajednica teklo je različitim tempom od pojedine useljeničke države do države, a postoje i iznimke jer se primjerice u Novom Zelandu to nije dogodilo. Nakon raspada Jugoslavenskoga društva 1991. dio članova osnovao je Dalmatinsko kulturno društvo, a drugi dio Hrvatsko kulturno društvo. U Dalmatinskom kulturnom društvu članovi 
kojim Cohenovim tipom dijaspore obuhvatiti hrvatsko iseljeništvo u tom razdoblju? U ovom je kontekstu uz praksu izbjegavanja teme jugoslavenskih zajednica moguće postaviti tezu o utjecaju antimarksističke paradigme na izbor tema nakon 1991., slično kao što je bio obrnut slučaj u prethodnom razdoblju. Provedbom identične analize zaključak bi ipak bio da i tu tezu nije moguće potvrditi samo na temelju analize historiografskih tekstova, nego je nužno u istraživanje uključiti i druge okolnosti.

Dakle, u zaključnoj usporedbi dvaju analiziranih razdoblja može se sumirati da istraživanja povijesti hrvatskoga iseljeništva karakterizira dosljednost upotrebe tradicionalnih pristupa. Ona se očituje prvenstveno u pitanju izbora tema s obzirom na dominantnu zastupljenost političke i intelektualne povijesti, usmjerene prije svega na istaknute pojedince i organizacije. Najveća promjena došla je do izražaja pri micanju fokusa s jugoslavenskih iseljeničkih zajednica do Drugoga svjetskog rata na hrvatske iseljeničke zajednice nakon 1945. godine. Velike promjene nisu se dogodile ni u pitanjima upotrebe metodologije te samih interpretacija rezultata istraživanja. Može se tek primijetiti pokušaje šire kontekstualizacije razvoja iseljeničkih zajednica među radovima objavljenim nakon 1991. godine. Moguće je očekivati širenje toga trenda s obzirom na sve lakši pristup stranoj literaturi i arhivskim izvorima uslijed razvoja tehnike i tehnologije te širenje mogućnosti boravka na stranim istraživačkim institucijama. S obzirom na to, a u kontekstu uočenih karakteristika hrvatske historiografije koja se bavi iseljeničkom problematikom, ovom prilikom čini nam se važnim istaknuti vrlo bitno, a naizgled banalno pitanje, koje prije unutar domaće historiografije na teorijskoj razini nije bilo u većoj mjeri problematizirano: tko čini hrvatsku iseljeničku zajednicu, odnosno kako ju uopće definirati?

\section{Teorijski pristupi identitetu iseljeničkih zajednica}

S obzirom na uočeni prevladavajući fokus unutar hrvatske historiografije na one iseljeničke zajednice koje prema temeljnim karakteristikama (prije svega političkim i ideološkim stavovima) odgovaraju aktualno dominantnim društvenim vrijednostima, iz teorijske perspektive moguće je i u ovom pitanju primijeniti navedenu primjedbu tipološkim pristupima dijaspori općenito. Iseljeništvo se u kontekstu relativno usko postavljenih tema istraživanja u velikoj mjeri promatra kao statičan, a ne fluidan fenomen podložan promjenama tijekom svojega razvoja kao rezultatu intenzivne interakcije u trokutu između države iseljenja, države useljenja i samih iseljenika. Posebno to dolazi do izražaja kada se govori o povijesnom razvoju iseljeničkih zajednica u dužem trajanju, čemu društvena povijest teži. Longitudinalna analiza razvoja hrvatskoga iseljeništva u dugom trajanju pružila bi uvid u mogućnosti evolucije jednoga

mogu postati pojedinci iz svih krajeva SFRJ, no većinu čini druga, treća, pa i četvrta generacija useljenika, nasljednici iseljenika koji su se još prije Prvoga svjetskog rata ili tijekom međuratnoga razdoblja doselili u Novi Zeland. 
Cohenova tipa dijaspore $\mathrm{u}$ druge kao reakcije na promjene širih društvenih okolnosti. Naime, hrvatsko iseljeništvo, kao i sve ostale dijaspore, izrazito je heterogena zajednica. Heterogenost dijaspora rezultat je utjecaja različitih čimbenika identiteta kod pojedinaca i grupa, odnosno rezultat zamršene interakcije između politike, kulture i identiteta u zemlji iseljenja, ali i u useljeničkim društvima, na čijem se sjecištu formiraju migrantske zajednice. ${ }^{41}$

Osnovna podjela u pitanju identiteta iseljenika i povijesnoga razvoja njihovih zajednica odvija se u pravilu na temelju pripadnosti različitim valovima iseljavanja, jer su migracije po svojoj prirodi izrazito selektivne. U određenim uvjetima i u određenom vremenu iseljava se stanovništvo sličnih strukturnih obilježja, pa su razlike u dominantnim karakteristikama između različitih generacija naglašeno prisutne. ${ }^{42}$ Međugeneracijske granice u slučaju hrvatskih iseljenika označavaju ključne, „lomne” godine u nacionalnoj povijesti XX. stoljeća, što je najviše došlo do izražaja u drugoj polovini stoljeća, u sukobu između dijaspore formirane prije Drugoga svjetskog rata i one koja se formirala nakon rata. No, da bi se interpretirala sva kompleksnost materije, nužno ju je sagledati u okviru teorija identiteta, koje također prije nisu znatnije problematizirane u okviru hrvatske historiografije o iseljenicima, za razliku od drugih znanstvenih disciplina, primjerice u etnologiji, antropologiji i sociologiji.

$\mathrm{Na}$ temelju tih analiza može se zaključiti da su autori radova o hrvatskom iseljeništvu objavljenih u Časopisu za suvremenu povijest, kao i u većem dijelu cjelokupne hrvatske historiografije, etničkom identitetu iseljenika prvenstveno pristupali u skladu s primordijalnim teorijama, koje ga tumače kao primarno, trajno i fiksno obilježje svakoga pojedinca. ${ }^{43}$ Hrvatskim ili prije jugoslavenskim iseljeničkim zajednicama za čiji je povijesni razvoj pokazivan interes smatrane su u pravilu one zajednice čije su temeljne aktivnosti bile u skladu s normama i vrijednostima koje je promicao trenutačni politički sustav u domovini. Može se primijetiti, opet paradoksalno, da se taj princip nije slijedio $u$ istraživanjima društvenih aktera u samoj Hrvatskoj.

Nasuprot primordijalnom pristupu etničkom identitetu razvili su se modernistički pristupi, koji naglašavaju promjenjivost i fluidnost etničkoga identiteta, koji je promatran prvenstveno kao socijalni konstrukt oblikovan društvenim okolnostima. ${ }^{44} \mathrm{U}$ aktualizaciji toga tipa pristupa fenomenu migracija definitivno se krije veliki potencijal za metodološki iskorak unutar hrvatske historiografije jer bi veći fokus na razradi teorijskoga okvira i metodoloških pristupa u tom smislu omogućio cjelovitije i dublje razumijevanje društvenoga procesa i njegovu širu interpretaciju. Razlike u identitetu između različitih generacija iseljenika bile su rezultat izrazito naglašenih razlika u ključnim trenucima formiranja njihovih zajednica, i u Hrvatskoj i u zemlji useljenja. No, one

\footnotetext{
${ }^{41}$ Usp. GABACCIA, Italy's many diasporas.

${ }^{42}$ ČIZMIĆ, ŽIVIĆ, „Vanjske migracije stanovništva Hrvatske”, 57-58.

${ }^{43}$ GRBIĆ JAKOPOVIĆ, Multipliciranje zavičaja i domovina, 44, 53.

44 Isto, 45-54.
} 
su očito nastavile evoluirati u skladu sa širim društvenim promjenama. Stoga je važno kontekstualizirati događaje i procese u vremenu i prostoru, čemu upravo društvena povijest teži. Pritom valja spomenuti i niz drugih čimbenika koji utječu na identitet iseljenika (spol, razina obrazovanja, mjesto i regija podrijetla itd.) te doprinose daljnjoj heterogenosti unutar pojedine zajednice. ${ }^{45}$

U skladu s tim, u srodnim disciplinama kao što su spomenute etnologija, antropologija i sociologija razvoj bilježe postmodernistički pristupi istraživanju etničkoga identiteta, koji dijasporu promatraju prvenstveno kao proces. ${ }^{46}$ Temelje se na postmodernističkom razumijevanju procesa globalizacije i pojmu transnacionalizma, odnosno trajnih prekograničnih odnosa. ${ }^{47}$ Transnacionalizam (u značenju transcendiranja države, tj. prekoračivanja granica nacionalnih država) naglašava povezanost iseljenika, bivših iseljenika te stanovništva koje nije migriralo unutar i između zemlje podrijetla i odredišta. Pridonosi shvaćanju migracija kao multilokalnoga fenomena, povezujući zemlje dolaska i odlaska, za razliku od prethodnoga shvaćanja, prema kojem su to bile dvije odvojene sfere. Ta promjena perspektive omogućena je prethodnom spoznajom sociologa i ostalih društvenih znanstvenika o tome da se u glavnini istraživanja implicitno poistovjećuju granice društva $s$ granicama nacionalne države, kao da društveni odnosi i veze prestaju s granicama nacija-država, a radi se o tzv. metodološkom nacionalizmu, tj. implicitnoj neosviještenoj navici istraživača. ${ }^{48}$ Taj -izam karakterizira gotovo glavninu društveno-znanstvene produkcije i njegovo osvješćivanje nije samo znanstvena kritika nego ide i u smjeru proširivanja vidika, odnosno podizanja svijesti o tome da promatrani društveni fenomeni često nadilaze državne granice, ali i da naša nacionalna pozicioniranost uvjetuje određene znanstvene zaključke. Posebno je to aktualno $\mathrm{u}$ istraživanju migracija kao inherentno multilokalnoga fenomena, odnosno fenomena koji seže izvan nacionalnih granica, te ga je stoga teško obuhvatiti koristeći se samo jednonacionalnom perspektivom. ${ }^{49}$ Transnacionalizam stoga baca novo svjetlo na pojmove poput identiteta, pripadnosti ili integracije jer naglašava mogućnost da migranti održavaju veze i osjećaje pripadnosti na više lokacija/država. Taj tip odnosa razvija se s obzirom na razvoj tehnike i tehnologije koji omogućuje stalnu interakciju između zemlje useljenja i iseljenja, pri čemu dio migranata u posljednje vrijeme praktički živi podjednako na oba odredišta. Zato se u etnologiji i antropologiji kao prikladniji pojam od transnacionalnosti

\footnotetext{
${ }_{45}$ Usp. COLIC-PEISKER, Migration, Class, and Transnational Identities; SKRBIŠ, Long Distance Nationalism.

${ }^{46}$ BERNS-McGOWN, „Redefining 'diaspora”, 15.

47 Usp. VERTOVEC, Transnationalism.

${ }^{48}$ KUTI, BOŽIĆ, „Metodološki nacionalizam u društvenim znanostima”, 325-344.

${ }^{49}$ Kao primjer metodološkoga nacionalizma Kuti i Božić navode primjer smatranja „vlastitom dijasporom” odavno asimiliranih potomaka iseljenika ili onih s razvijenim višestrukim nacionalnim identitetima. S druge strane u useljeničkim društvima često se nailazi na statističke konstrukte koji neodgovarajuće opisuju određene jasno odijeljene skupine doseljenika, npr. „državljani bivše Jugoslavije ili bivšeg Sovjetskog Saveza”. Usp. Isto, 340.
} 
počinje upotrebljavati translokalnost. ${ }^{50}$ No za istraživanje tih fenomena iz historiografske perspektive potrebna je ipak određena vremenska distanca.

Osvrt na analizu te mogućnosti i perspektive daljnjih istraživanja hrvatskoga iseljeništva

Može se zaključiti da veći dio hrvatske historiografije, barem s obzirom na analizirani uzorak radova objavljenih u Časopisu za suvremenu povijest, u istraživanju tema posvećenih iseljeništvu nije u znatnijoj mjeri pridavao pozornost dubljoj razradi teorijskoga i metodološkoga okvira, odnosno primjeni nekog od razvijenih modela. Stoga najveći potencijal budućega razvoja ovoga polja leži, smatramo, upravo u razvoju toga znanstvenog aspekta, primarno kroz interdisciplinarnu perspektivu. Posebno to vrijedi u smislu kombiniranja historiografskoga, sociološkoga, etnološkoga i antropološkoga pristupa istraživanju razvoja iseljeničkih zajednica te procesa migracija u cjelini jer te discipline uslijed svoje komplementarnosti pružaju pogodan okvir i teorijsku podlogu istraživanju teme. No, pritom je svakako važno zadržati osnovne karakteristike historiografske analize, u kojoj je rad s arhivskim izvorima te njihova interpretacija temelj istraživačkoga postupka i od najveće je važnosti. Teoretiziranje nije cilj sam po sebi, nego tek snažna uklopljenost, odnosno isprepletenost izvorne građe i teorije u cilju interpretacije rezultata znači postizanje znatnijega znanstvenog doprinosa. To će omogućiti usporedbu s drugim iseljeničkim grupama, narodima i nacijama u prostoru i vremenu te donošenje zaključaka, odnosno potvrdu ili opovrgavanje postavljenih hipoteza u kontekstu konkretnoga istraživanja. Ta metoda ujedno će rezultirati i boljim shvaćanjem prirode migracija kao društvenoga fenomena.

Taj tip pristupa razvija se u stranim historiografijama i srodnim disciplinama već desetljećima. No, to je i jedan od razloga što ne postoji općeprihvaćena teorija migracija, nego čitav niz pokušaja sagledavanja toga kompleksnog fenomena. Svaki od tih pristupa vodi se određenom paradigmom te u pristupu naglašava pojedini aspekt cjelokupnoga procesa, pa posljedično u većoj ili manjoj mjeri doprinosi njegovu razumijevanju. Posebno to dolazi do izražaja s obzirom na različitost zainteresiranih disciplina, čiji se predstavnici u istraživanjima vode interesima pojedine struke i naglašavaju ono što ih zanima - etnolozi, antropolozi, sociolozi, povjesničari, ekonomisti, geografi... Širini lepeze objašnjenja dalje doprinosi i sama priroda fenomena, koji ovisno o vremenu i prostoru mijenja svoje bitne karakteristike. No, unatoč tome, pokušaji teorijskih objašnjenja itekako su korisni, a različiti pristupi uglavnom su i kompatibilni te se dopunjavaju, a različite se teorije automatski ne isključuju.

Istraživanje povijesti iseljeništva u kontekstu hrvatske historiografije nije velika iznimka u pitanju nedovoljne razvijenosti istraživanja društva unutar suvremene povijesti, odnosno operacionalizacije teorijskoga okvira u istraži-

${ }^{50}$ GRBIĆ JAKOPOVIĆ, Multipliciranje zavičaja i domovina, 29-30. 
vanjima. U nešto većoj mjeri ipak dolazi do izražaja s obzirom na nedostupnost odnosno otežanu dostupnost pisanih i usmenih (usmena povijest) izvora, koji bi bili temelj toga pristupa. Sličnu ulogu imala je i ograničena dostupnost relevantne literature o povijesnom razvoju zemalja i društava useljenja. Stoga je izostala šira kontekstualizacija djelovanja iseljenika i njihova svakodnevnoga života, a razvoj iseljeničkih zajednica tumačio se gotovo isključivo kroz prizmu događaja u Hrvatskoj, s fokusom na njihova nastojanja očuvanja nacionalnoga identiteta. Među temama koje se istražuju i dalje dominira usredotočenost na istaknute pojedince i organizacije, a u pitanju pristupa osnovna je karakteristika snažna utemeljenost u pristupima klasične političke ili eventualno intelektualne povijesti. Naznačena nacionalna uokvirenost istraživanja iseljeništva opisana prije kao metodološki nacionalizam mogla bi se prevladati većom međunarodnom suradnjom, odnosno koncipiranjem istraživanja koja bi obuhvatila više lokaliteta ili uključila znanstvenike iz drugih zemalja. Takve suradnje, iako teže ostvarive, osigurale bi sagledavanje različitih konteksta i veću raznolikost istraživanih tema. Razvoju te ideje u praksi u budućnosti svakako ide u prilog sve veći broj boravaka hrvatskih znanstvenika, osobito mlađe generacije, na stručnom usavršavanju na međunarodnim institucijama, kao i sve lakša dostupnost literature preko interneta, koji postaje i sve važniji čimbenik u pristupu izvorima jer se u pojedinim razvijenijim zemljama arhivski fondovi u sve većoj mjeri digitaliziraju te su javno dostupni na internetu. Sve to unapređuje mogućnosti proučavanja povijesnoga razvoja hrvatskoga iseljeništva, ali i njegove usporedbe s drugim iseljeničkim zajednicama unutar useljeničkih društava, kao i analizu dinamike odnosa između Hrvatske i iseljeničkih zajednica, kao i useljeničkih zemalja, što se posljedično reflektiralo na iseljenike. Time će se ujedno omogućiti stvaranje integrativne povijesti modernoga hrvatskog društva i njegova iseljeništva, kao i znatniji doprinos istraživanju povijesti useljeničkih zemalja i društava. Pritom bi se posljedično ostvarilo i bolje poznavanje doprinosa hrvatskih iseljeničkih zajednica razvoju brojnih aspekata useljeničkih društava, što se nikako ne smije podcijeniti.

\section{Literatura}

AGIČIĆ, Damir. „Hrvatski doktori u Pragu 1882.-1921. godine”. Časopis za suvremenu povijest 27 (1995), br. 1: 137-154.

AGIČIĆ, Damir. „Hrvatski studenti na češkom sveučilištu u Pragu 1882.1918. godine”. Časopis za suvremenu povijest 30 (1998), br. 2: 291-315.

AKENSON, Donald H. „The Historiography of English-Speaking Canada and the Concept of Diaspora: A Skeptical Appreciation". Canadian Historical Review 76 (1995), br. 3: 377-410.

ANTIĆ, Ljubomir. „Pokušaj stvaranja 'Hrvatskog saveza' među našim iseljenicima u Južnoj Americi 1913. godine”. Časopis za suvremenu povijest 15 (1983), br. 2: 43-62. 
ANTIĆ, Ljubomir. „Prilog istraživanju odnosa naših iseljenika u Južnoj Americi prema NOB-u s posebnim osvrtom na JNO na Pacifiku”. Časopis za suvremenu povijest 19 (1986), br. 1: 43-80.

ANTIĆ, Ljubomir. „Sukobi u jugoslavenskom iseljeničkom pokretu u Antofagasti (Čile) za vrijeme prvoga svjetskog rata i neki socijalni utjecaji na njih 1917. godine”. Časopis za suvremenu povijest 16 (1984), br. 2: 19-47.

ARANGO, Joaquín. „Explaining Migration: A Critical View”. International Social Science Journal 52 (2000), br. 165: 283-296.

BARTH, Fredrik. „Introduction”. U: Ethnic Groups and Boundaries: The Social Organization of Culture Difference, ur. Fredrik Barth. London: Allen \& Unwin, 1969, 9-38.

BEDNJANEC VUKOVIĆ, Aleksandra. „Prilozi o NDH u časopisu 'Hrvatska revija' od 1951. do 1971. godine”. Časopis za suvremenu povijest 32 (2000), br. 1: 73-96.

BENCETIĆ, Lidija. „Mons. Augustin Juretić - djelovanje u emigraciji kroz bilten Hrvatski dom”. Časopis za suvremenu povijest 45 (2013), br. 3: 461-484.

BERNS-McGOWN, Rima. "Redefining 'diaspora': The challenge of connection and inclusion". International Journal 63 (2008), br. 1: 3-21.

BEUS, Marina. „Suradnja Dominika Mandića i Jere Jareba u svjetlu korespondencije sačuvane u Mandićevoj ostavštini”. Časopis za suvremenu povijest 50 (2018), br. 3: 503-534.

BING, Albert. „Croatia down under': australski tisak o izbijanju rata u Hrvatskoj i raspadu Jugoslavije 1990.-1991." Časopis za suvremenu povijest 35 (2003), br. 3: 769-802.

BRUBAKER, Rogers. „The 'diaspora' diaspora”. Ethnic and Racial Studies 28 (2005), br. 1: 1-19.

BUĆIN, Rajka. „Iseljenički muzej u Zagrebu (1933. - 1940.)”. Časopis za suvremenu povijest 50 (2018), br. 2: 363-389. https://doi.org/10.22586/csp.v50i2.91

CASTLES, Stephen; MILLER, Mark J. The Age of Migration: International Population Movements in the Modern World. Houndmills: Palgrave Macmillan, 2009.

COHEN, Robin. Global Diasporas: An Introduction. London: UCL Press, 1997.

COLIC-PEISKER, Val. Migration, Class, and Transnational Identities: Croatians in Australia and America. Champaign: University of Illinois Press, 2008.

ČIZMIĆ, Ivan. „Reagiranja jugoslavenskih iseljenika na potpisivanje Münchenskog sporazuma 1938. god.” Časopis za suvremenu povijest 12 (1980), br. 3: 99-107.

ČIZMIĆ, Ivan; ŽIVIĆ, Dražen. „Vanjske migracije stanovništva Hrvatske - kritički osvrt”. U: Stanovništvo Hrvatske - dosadašnji razvoj i perspektive, ur. Dražen Živić, Nenad Pokos i Anka Mišetić. Zagreb: Institut društvenih znanosti Ivo Pilar, 2005, 55-69. 
De HAAS, Hein. Engaging diasporas. How governments and development agencies can support diaspora involvement in the development of origin countries. International Migration Institute, Oxford University. Pristup ostvaren 27. 4. 2019. http://citeseerx.ist.psu.edu/viewdoc/download?doi=10.1.1.690.4678\&re $\mathrm{p}=$ rep1\&type $=$ pdf.

„Demografi složni: Hrvatska ima manje od 4 milijuna stanovnika, ali postoji jedan ozbiljan problem”. Portal vijesti.rtl.hr, 23. 2. 2019. Pristup ostvaren 29. 4. 2019. https://vijesti.rtl.hr/novosti/hrvatska/3344795/demografi-sloznihrvatska-ima-manje-od-4-milijuna-stanovnika-ali-postoji-jedan-ozbiljanproblem/.

FAIST, Thomas. „Migrants as transnational development agents: an inquiry into the newest round of the migration-development nexus". Population, Space and Place 14 (2008), br. 1: 21-42.

FOX, Michael S. „Ante Ciliga, Trocki i državni kapitalizam: teorija, taktika i preispitivanje stavova u razdoblju čistki (1935.-1939.)”. Časopis za suvremenu povijest 26 (1994), br. 3: 427-449.

GABACCIA, Donna. Italy's many diasporas. Seattle: University of Washington Press, 2000.

GRBIĆ JAKOPOVIĆ, Jadranka. Multipliciranje zavičaja i domovina. Hrvatska dijaspora: kronologija, destinacija i identitet. Zagreb: Filozofski fakultet, 2014.

HAMERŠAK, Filip. „Josip Jedlowski - životopis (s bilješkama za transnacionalnu povijest jedne građanske obitelji)". Časopis za suvremenu povijest 37 (2005), br. 1: 101-128.

HRANILOVIĆ, Nada. „List 'Zajedničar' i narodnooslobodilačka borba u Jugoslaviji”. Časopis za suvremenu povijest 18 (1986), br. 2: 49-64.

HRANILOVIĆ, Nada. „Novinarska djelatnost don Nike Grškovića u SAD”. Časopis za suvremenu povijest 16 (1984), br. 3: 19-33.

HRSTIĆ, Ivan. „Dnevnik Ivana Čovića - prilog istraživanju dobrovoljačkog pokreta među Hrvatima u SAD-u u vrijeme Prvoga svjetskog rata”. Časopis za suvremenu povijest 42 (2010), br. 1: 157-177.

JANDRIĆ, Berislav. „Stajališta Hrvatske političke emigracije o hrvatskom proljeću iznesena u najznačajnijem emigrantskom časopisu Hrvatskoj reviji”. Časopis za suvremenu povijest 35 (2003), br. 2: 431-461.

JANKOVIĆ, Branimir. Mijenjanje sebe same. Preobrazbe hrvatske historiografije kasnog socijalizma. Zagreb: Srednja Europa, 2016.

JAREB, Jere. „Prilog povijesti hrvatskog iseljeništva u Sjedinjenim Američkim Državama 1941.-1947”. Časopis za suvremenu povijest 37 (2005), br. 1: 37-70.

JAREB, Jere. „Publikacije domobransko-ustaškog pokreta u izbjeglištvu i iseljeništvu 1929.-1944. - I. dio”. Časopis za suvremenu povijest 26 (1994), br. 2: 241-255. 
JAREB, Jere. „Publikacije domobransko-ustaškog pokreta u izbjeglištvu i iseljeništvu 1929.-1944. - II. dio". Časopis za suvremenu povijest 26 (1994), br. 3: 413-426.

JELASKA MARIJAN, Zdravka. „Pedeset godina Časopisa za suvremenu povijest: bibliometrijska analiza (1969. - 2018.)". Časopis za suvremenu povijest 51 (2019), br. 1: 59-96. https://doi.org/10.22586/csp.v51i1.8471

JELIĆ-BUTIĆ, Fikreta. „Prilog proučavanju djelatnosti ustaša do 1941.” Časopis za suvremenu povijest 1 (1969), br. 1-2: 55-91.

JONJIĆ, Tomislav; MATKOVIĆ, Stjepan. „Novi prilozi za životopis Mile Budaka uoči Drugoga svjetskog rata”. Časopis za suvremenu povijest 40 (2008), br. 2: 425-453.

KING, Russel. „Towards a new map of European migration”. International Journal of Population Geography 8 (2002), br. 2: 89-106.

KING, Russell; CHRISTOU, Anastasia. „Cultural geographies of counterdiasporic migration: perspectives from the study of second-generation 'returnees' to Greece". Population, Space and Place 16 (2010), br. 2: 103-119.

KOLAR-DIMITRIJEVIĆ, Mira. „Odnos KPJ prema jugoslavenskoj radničkoj emigraciji u međuratnom razdoblju”. Časopis za suvremenu povijest 16 (1984), br. 2: 65-83.

KOPRIVICA-OŠTRIĆ, Stanislava. „Jugoslavenski dobrovoljci u jedinicama španjolske republikanske vojske 1936.-1939." Časopis za suvremenu povijest 19 (1987), br. 2: 1-26.

KRALJEVIĆ, Iva. „Matica iseljenika Hrvatske 1964.-1968.” Časopis za suvremenu povijest 41 (2009), br. 1: 71-92.

KRIŠTO, Jure. „Čuvari svoje braće: policijsko nadgledanje američkih Hrvata tijekom Drugoga svjetskog rata”. Časopis za suvremenu povijest 35 (2003), br. 2: 407-430.

KRIŠTO, Jure. „Hrvatska historiografija kroz trideset godišta Časopisa za suvremenu povijest (1969.-1999.)”. Društvena istraživanja 11 (2002), br. 1: 171186.

KUTI, Simona; BOŽIĆ, Saša. „Metodološki nacionalizam u društvenim znanostima - konzekvence za društvena istraživanja”. Migracijske $i$ etničke teme 27 (2011), br. 3: 325-344.

MARINOVIĆ GOLUBIĆ, Marica. „Useljavanje u tradicionalno iseljenička područja: istraživanje slučaja otoka Korčule”. Doktorska disertacija, Sveučilište u Zagrebu, 2015.

MARTINIĆ BEROŠ, Mateo. „Nacionalno-političke kontroverze među hrvatskim iseljenicima u Magallanesu (1896.-1918.)”. Časopis za suvremenu povijest 34 (2002), br. 3: 735-759.

MATKOVIĆ, Hrvoje. „Prilog proučavanju političke djelatnosti Jurja Krnjevića”. Časopis za suvremenu povijest 34 (2002), br. 1: 93-106. 
McAULIFFE, Marie; RUHS, Martin. World Migration Report 2018. Geneva: International Organization for Migration, 2017.

MILOŠEVIĆ, Srđan. „Emigrantska pisma Vladka Mačeka knezu Pavlu Karađorđeviću (1946. - 1952.)". Časopis za suvremenu povijest 44 (2012), br. 2: 299-322.

RUŽIĆ, Snježana. „'Immigration history' i njezino mjesto u sjevernoameričkoj historiografiji”. Časopis za suvremenu povijest 34 (2002), br. 3: 761-779.

SAFRAN, William. „Diasporas in Modern Societies: Myths of Homeland and Return". Diaspora 1 (1991), br. 1: 83-99.

SCHMIDT, Amy. „Vladko Maček i Hrvatska seljačka stranka: prizori iz izbjeglištva”. Časopis za suvremenu povijest 37 (2005), br. 2: 407-422.

SINATTI, Giulia; HORST, Cindy. „Migrants as agents of development: Diaspora engagement discourse and practice in Europe". Ethnicities 15 (2015), br. 1: 134-152.

SKRBIŠ, Zlatko. Long Distance Nationalism: Diasporas, Homelands, and Identities. Sydney: Ashgate, 2000.

STRČIĆ, Petar. „Prilog za biografiju Ante Cilige”. Časopis za suvremenu povijest 20 (1988), br. 3: 15-49.

ŠARIĆ, Tatjana. „Bleiburške žrtve na stranicama Hrvatske revije”. Časopis za suvremenu povijest 36 (2004), br. 2: 505-521.

TOMAS, Domagoj. „Pogled na život i djelo don Ivana Tomasa kroz Hrvatsku reviju”. Časopis za suvremenu povijest 47 (2015), br. 1: 39-59.

VALENTIĆ, Mirko. „O denacionalizaciji Gradišćanskih Hrvata”. Časopis za suvremenu povijest 9 (1977), br. 1: 171-178.

VALENTIĆ, Mirko. „Obilježja povijesnog razvitka Gradišćanskih Hrvata”. Časopis za suvremenu povijest 9 (1977), br. 1: 95-108.

VALENTIĆ, Mirko. „Školska problematika Gradišćanskih Hrvata”. Časopis za suvremenu povijest 9 (1977), br. 1: 121-132.

VERTOVEC, Steven. Transnationalism. Abingdon, Oxon: Routledge, 2009.

VUKAS, Budislav. „Međunarodnopravna zaštita narodnih manjina u Austriji - položaj Gradišćanskih Hrvata”. Časopis za suvremenu povijest 9 (1977), br. 1: 47-67.

ZORN, Tone. „Manjinsko pitanje i jugoslavensko-austrijski odnosi u godinama 1945.-1975.” Časopis za suvremenu povijest 9 (1977), br. 1: 25-45. 


\section{SUMMARY}

\section{From Chronology towards Theoretical Concepts - the Problem of Émigrés in Croatian Historiography as Evidenced by Papers Published in the Journal of Contemporary History}

This article encompasses an analysis of research on the process of the formation and development of Croatian émigré communities in Croatian historiography based on 39 papers devoted to this topic, published from 1969 to 2018. The analysis was conducted on two levels. The general (under)representation of the topic in the context of Croatian historiography as a whole is examined first, followed by the issue of the influence of the dominant narrative on research through three key domains: the selection of topics, the use of characteristic methodology, and the interpretation itself. In this context, two periods have been examined separately - during the Socialist Federal Republic of Yugoslavia and after the Republic of Croatia achieved independence. Parallel with this part of the analysis, the basic characteristics of papers on the topic of Croatian émigrés have been contextualised in regard to the achievements of foreign historiography and related scientific disciplines from the aspect of applying theoretical and methodological research frameworks.

The reasons for the poor representation of this topic include high politicisation in regard to the critical stance of a large part of the émigré population towards the political system in Yugoslavia till 1991 and the difficult accessibility of archival material and relevant literature on immigrant associations. The analysis did not find any direct influence of politics, i.e. ideology, on the researchers, but there was a shift in the focus of research in line with changes in the social context, from the (pro-)Yugoslav émigré communities towards the predominantly anti-Yugoslav ones in works published after 1991. The predominant characteristic of the analysed works in both periods is the lack of an interpretation of the activities of examined individuals, events, and processes in a broader theoretical framework. Accordingly, a narrow focus on sources is predominant in the methodological sense, as is the lack of contextualisation of the development of Croatian émigré communities within the frame of immigrant associations. They are approached as homogenous groups, and their development is primarily interpreted in the context of events in Croatia. Following everything stated above, this paper points to the necessity of applying developed theoretical and methodological models through an interdisciplinary perspective.

Key words: Croatian émigrés; historiography; social history; interdisciplinary approach; Journal of Contemporary History 